\title{
Does religion affect political engagement of the youth at the tertiary level of education? The case of undergraduate students at a South African university
}

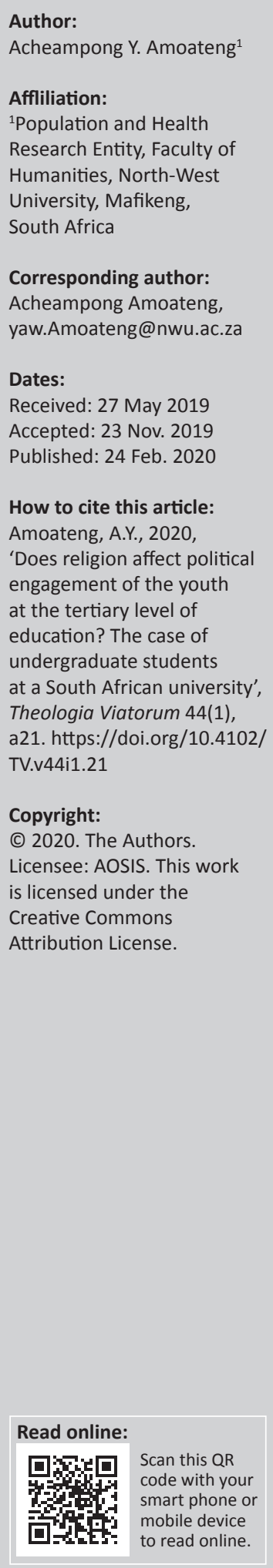

The aim of this study is to examine religion's effect on the political engagement of the youth using data from a sample of undergraduate students at the North-West University in South Africa. The logit regression model analysis showed that contrary to what the participation literature would expect, socio-economic factors such as parental education, age and gender were not significant predictors of the political engagement of the youth. However, consistent with the study's conceptualisation of political engagement as a multi-dimensional concept, gender, race, ethnicity and family structure were all significantly predictive of different aspects of political engagement of the youth. Males were more likely than females to engage in politics, while black Africans were politically more active than the white and mixed race South Africans. While both self-rated religiosity and importance of religion in the life of the youth predicted their political engagement, their influences were in opposite directions. Finally, civic skills acquired in non-religious contexts were positively associated with every aspect of political engagement of the youth.

Keywords: religion; political engagement; youth; civic skills; logit regression.

\section{Introduction}

Despite the age-old debate about the schism between church and state, the empirical evidence about religion's effect on civic engagement of the youth is thin. This relative paucity of empirical evidence on the effect of religion on the political participation of the youth is questionable in the face of what appears to be the increasing importance of religion in the lives of young people, in modern, secular society (Smith 2003; Smith \& Denton 2005). Nowhere has the paucity of the empirical evidence on the effect of religion on young people been more manifest than in the area of youth development where religion has been one of the social forces that have been responsible for the emergence of a paradigm that conceptualises youth as an unproblematic period in the life span (Gore 2003; Lerner 2002; Lerner et al. 2002; Smith 2003).

Many empirical studies across myriad areas of concern with regard to the youth have associated various measures of religion with a variety of positive, desirable outcomes in many contexts. For instance, in the United States, many scholars have found measures of religion to be inversely associated with juvenile drug, alcohol, tobacco use, delinquency (e.g. Evans et al. 1995; Wallace \& Williams 1997), thoughts of suicide, attempted suicide and actual suicide among American teenagers (Donahue 1995). On the other hand, religiosity has been found to be associated with lower levels of depression and hopelessness (Smith \& Denton 2005; Wright, Frost \& Wisecarver 1993).

In South Africa, the empirical evidence on the inverse association between measures of religion and various risk behaviours by the youth has been mounting over the years (e.g. Amoateng, Barber \& Erickson 2006; Amoateng, Setlalentoa and Udomboso 2017; Chauke, Van der Heever \& Hoque 2015; Flisher et al. 1996; Morojele et al. 2006; Seggie 2012). Existing evidence is quite emphatic that religious participation may be associated with greater political and civic involvement, especially during young adulthood (Serow \& Dreyden 1990; Smith 1999; Youniss, McLellan \& Yates 1999). In explaining how religion affects political participation, Smith (2003) has observed that religion provides the organisational contexts and cultural substance which engenders spiritual experiences of the youth which help cement their moral commitments and constructive life practices. Other studies have confirmed this feature of organised religion by observing that associational membership generally correlates with almost every measure of political engagement (e.g. Diaz 1996; Djupe \& Grant 2001; Putnam 1993a, 1993b), while others 
have observed that religious organisations' central role is that they serve as important conduits of political information and recruitment (Ammerman 1997; Huckfeldt \& Sprague 1995). This positive approach to problems associated with the youth projects the notion that positive adolescent development entails a merger of moral and civic identity which results in engagement with civil society institutions such as religion by the youth (Crompton 1998; Lerner et al. 2002).

\section{The present study}

The introduction has shown that despite the growing empirical evidence about the role of religion in engendering positive attitudes and behaviours among the youth in areas of concern such as drug, alcohol and tobacco use, and risky sexual behaviours, there has been a glaring gap in our knowledge of the role that religion plays in the lives of the youth with regard to their political participation. There are two plausible reasons for this void in the literature. First, while the explosion of studies in the area of religion's role in substance abuse and risky sexual behaviours among the youth is a welcome development, these behaviours constitute a tiny fraction of the wide range of behaviours of the youth that are of interest to policy-makers and academics alike. Second, the context in which religion has been found to be an enabler of positive behaviours is mainly Western and therefore cannot be generalised to other non-Western contexts.

For example, historically in the African context, the line between religion and politics blurred in pre-colonial society because of the critical role that priests and priestesses played in the affairs of the state. This blurring of the line between religion and politics deepened further during the decolonisation period with the emergence of the so-called Independent or African churches and the political stances they adopted against colonial oppression. The brand of liberation theology preached by these churches thrust them into the political limelight as church leaders began to question hitherto political structures that disadvantaged the African majorities in the colonies.

The 21st century exemplar of this phenomenon of Africanisation of the churches is clearly manifest in the role played by the clergy as personified in, for example, Archbishop Desmond Tutu in the struggle against apartheid in South Africa. It is our contention that this syncretism of the sacred and mundane in regard to the organisation of religion in Africa would ensure that religion plays a different role in the continent compared to other contexts. Thus, the importance of understanding religion's role in political engagement of the youth cannot be overemphasised, especially in the face of the scramble among both politicians and academics in Africa to seek solutions to violent aspects of political engagement of the youth in recent years.

It is against this background of the paucity of empirical evidence on the relationship between religion and political participation of the youth in South Africa that this study is undertaken. Specifically, the study examines whether religion affects political engagement among the youth in South Africa by using as a case study a sample of undergraduate students at the University of North-West in South Africa. To examine the independent effect of religion on the political engagement of the youth, we control for the effect of social structural factors such as gender, race, ethnicity and family structure.

\section{Review of the literature}

Political engagement or participation is often skewed because of the fact that political actors do not come from homogenous backgrounds. The empirical evidence suggests that social, economic, demographic and cultural factors such as age, gender, education, religion, social class and ethnicity all have important bearings on political participation (e.g. Chatora 2012; Isaksson 2014). For example, the existing literature shows that age is consistently identified as the most powerful demographic predictor of political involvement. Numerous national and cross-national studies have found age gaps in political participation, particularly in electoral participation (Cross \& Young 2008; Grasso 2013). Despite the consensus that young people engage in politics through a variety of ways, the empirical evidence suggests that young people participate to a lesser extent in politics than their older counterparts. For example, a report by the UNDP (2013) showed that young people aged 15-25 years who constitute a fifth of the world population are not represented in political institutions such as parliaments and many do not participate in elections.

In the United States, many studies have found that young people are less likely to vote or engage in any civic or political behaviours prior to elections (e.g. Flanagan \& Levine 2010; Garcia-Penalosa \& Konte 2013). In South Africa, in a study of undergraduate students at the University of Johannesburg, Amoateng (2015) found a positive association between age and political participation. Specifically, he found that younger adolescents were less likely to engage in political activities compared to their older counterparts.

There have been some attempts to empirically assess the role of religious practices in shaping political participation. The argument is that those with significant involvement in religious groups are more likely to vote or be politically active and committed. For instance, Esser and De Vreese (2007) found that religiousness (religious attachment) was a strong predictor of youth turnout in the United States and in Europe. Teney and Hanquinet (2012) showed that belonging to a religious organisation leads to a greater political participation. They found that young people involved in religious organisation and attending religious services tended to be more politically engaged than religious youth who did not take part in any religious activities. Verba, Schlozman and Brady (1995) found that in the United States while variation in ethnic group participation was related to socio-economic differences among them, it was derived from the acquisition of civic skills through their associational memberships and, in particular, from their experiences in church. According to them, Catholic and Protestant churches develop different levels of skills so the relatively low level of Latino political participation was explained by 
a predominantly Catholic affiliation. In explaining this role of religion, they noted (Verba et al. 1995):

Even when church activists pursue endeavours with no demonstrable political content...they have opportunities to develop skills that are relevant for politics. These skill-endowing opportunities can serve as a compensatory function, enhancing political resources among church activists whose educational and occupational levels might otherwise predispose them to political quiescence. (p. 4)

Gender has been identified as an important predictor of political participation in the broader literature. Owing to the patriarchal nature of most societies, politics (i.e. political affairs and decision-making) is mostly viewed as a male domain (e.g. Sossou 2011); it is therefore likely that political involvement will be affected by gender roles or norms. As predicted, there is a persisting gender gap with respect to most forms of political engagement, and it is generally unevenly gendered in favour of men (Inglehart \& Norris 2000). Broadly, research on gender gaps in political involvement in the developing world, including Ghana, reveals similar global patterns (Isaksson 2014; Isaksson, Kotsadam \& Nerman 2012; Kuenzi \& Lambright 2010). In his study involving undergraduate students at the University of Johannesburg, Amoateng (2015) found this gender gap in that the male political participation rate was about 10 percentage points higher than their female counterparts.

The social psychological approach or the socio-economic status model (e.g. Kam \& Palmer 2008; Verba \& Nie 1972) argues that individuals, especially those from upper-status backgrounds, develop 'civic' attitudes that predispose them to participate in politics. These are individuals who generally possess resources such as good education and their relative financial security allows them to invest time and money on organisation which gives them further advantage in the political domain. Thus, the socio-economic status (SES) model highlights education as a key determinant of political participation as it is theorised to develop civic skills required for political engagement (Resnick \& Casale 2011). Thus, it is consistently found that the higher or better-educated are more likely to be interested in politics, become politically involved and/or to vote (Armingeon \& Schädel 2015; Isaksson 2014; Kuenzi \& Lambright 2010).

However, some research suggests a clearer impact of education in some countries than in others. For example, Bratton (1999) found that education had no impact on overall political participation in Zambia. Nonetheless, the level of educational attainment is found to positively shape political activism in the youth: higher education has a very strong influence on youth participation in most political activities (e.g. Sloam 2013). Grasso (2013) shows that education levels have a differential impact on young people's political involvement in both the United Kingdom and Italy. Educational status exerted a particularly strong impact on the political engagement of the youth in Britain, in which young educationally qualified people tend to be more politically engaged (Henn \& Foard 2014; Henn, Weinstein \& Forrest 2005).
It has been found that well-educated young Africans are more likely to engage in protest activities to express dissatisfaction (Resnick \& Casale 2011), although education levels did not correlate with youth voter turnout in sub-Saharan Africa (Resnick \& Casale 2014). In South Africa, analysis of gender differences in electoral participation has revealed that educational attainment has no significant impact on voting for both men and women (Roberts, Struwing \& Grossberg 2012), while Amoateng (2015) did not observe any statistically significant relationship between maternal education and political engagement of the youth for his student sample.

\section{Data and methods}

The data for this study are obtained from the Religion and Positive Youth Development Project, an initiative of the Faculty of Humanities of the North-West University (Mafikeng Campus). Both quantitative and qualitative techniques were used in a mixed-method approach. To this effective, both probability and non-probability sampling techniques were used to interview a total of 1430 undergraduate students across the three campuses of the University (i.e. Mafikeng, Potchefstroom and Vaal campuses). In the probability sampling procedure, stratified random sampling design was employed by disaggregating the samples from each campus based on faculty using proportional allocation to size based on the population of students in the faculties. In the non-probability sampling procedure, the faculty samples were disaggregated based on the year of study, whereby the sample numbers allocated to each year of study were random. Generally, the least sample numbers were allocated to the first-year students, while the greatest sample numbers were allocated to the third- and fourth-year students.

Finally, in selecting the students to be included in the sample, convenience sampling was used whereby trained students interviewed the numbers of students in each faculty, school and gender as determined a priori through the stratified random sampling procedure. Out of the target sample of 1430 students, 1144 students completed the interview, yielding a response rate of $80 \%$. Students responded to a battery of questions relating to issues such as religious affiliation, religiosity, spirituality, belief in God, sexuality, political behaviour, attitudes towards foreigners and attitudes towards and use of various licit and illicit substances. Data collection took place between September 2015 and April 2016. ${ }^{1}$

\section{Measures of variables Dependent variable}

The dependent variable in this study is political engagement of the youth which has four dimensions, namely family political discussion, peer political discussion, political party discussion and attempts to influence the political process. The four dimensions of political engagement represent 1.Data collection was halted towards the end of 2015 because of the student unrest on campuses around the country. 
non-electoral political engagement as opposed to electoral engagements such as registration to vote or actual voting for a particular political party or candidate. The four dimensions of political engagement are measured by:

How often youth discuss politics with.... parents/other family members; friends/classmates with similar and different political views on campus; members of political organisations on and outside campus; and attempts to influence the political process?

These four dimensions of political engagement are measured on a five-point Likert scale ranging from 1, 'never'; 2, 'rarely'; 3, 'sometimes'; 4, 'often' to 5, 'always'. Each of the four dimensions of civic engagement is created as a summated score of the respective items after conducting principal component analysis (PCA) of the items using Varimax rotation. Table 1 shows the number of items for each of the constructs of political engagement, their factor loadings and alpha levels.

\section{Independent variables}

Religion is the main independent variable in this study and is measured as a multi-dimensional concept with four main dimensions as follows: (1) Self-rated religiosity. This is measured by asking the respondent, 'How religious do you consider yourself to be?' It is measured using a five-point Likert scale ranging from 'not at all religious' to 'extremely religious'; (2) Perception of the importance of religion in one's life/a family's life which was measured by asking the student: 'How important is religion in your life/your family's life?' This is measured using a five-point Likert scale ranging from 'not at all important' to 'extremely important'; (3) Frequency of church attendance. Students are asked to indicate 'How often do you and your family attend church/mosque/temple/synagogue services?' Frequency of family church attendance is measured on a five-point Likert scale ranging from 0 , 'never'; 1 , 'Only on special occasions'; 2 , 'occasionally (several times a year)'; 3, 'frequent attendance'; 4, 'fairly regular (almost weekly)'; 5, 'Regular (Weekly)'. (4) Religious affiliation is measured by three categories. For this dimension, students are asked to indicate the religious organisation they belong to and three broad affiliations are measured after collapsing categories with fewer cases: Christian (Protestant), Christian (Catholic) and other. Besides the four dimensions of religion which was the main independent variable in the study, we also control for a number of individual background socio-demographic characteristics including age, gender, race or ethnicity (home language), family's SES and parental educational attainment.

Age is measured as a continuous variable, while both mother's and father's educational attainments are measured at the ordinal level with the question: 'Please indicate the highest level of your mother's or father's education'. The responses range from 1, 'no education' to 7, 'postgraduate degree'. Family structure is measured at the nominal level with the question: 'at home, which parents or guardian do you live with?' The responses ranged from 1, 'living with both biological parents at home'; 2 , 'living with a single parent'; 3 , 'living with other relatives'.

Family's SES is measured at the ordinal level with the question: 'How would you describe your family's socio-economic status compared to other families in the area where you live?' The responses range from 1, 'poorer than most'; 2, 'about the same as most' to 3 , 'richer than most'. In addition to these socio-demographic characteristics, we control for the student's perception of the importance of participating in selected political activities. This variable is measured by the question:

How important is it for students to participate in the following activities (Elections for national government; Elections for provincial government; Elections for local government; and Elections for student political associations?).

Importance for students to participate in the political process is measured on a five-point Likert scale ranging from 1 , 'not at all important'; 2, 'Slightly important'; 3, 'neutral'; 4, 'moderately important' to 5, 'very important'. It is expected that students who perceive the importance of such civic responsibilities will be more likely to engage in the various civic activities. Finally, we control for civic skills of the respondent which is a summated scale of five items. The question asked to the

TABLE 1: Factor analysis of political engagement variables.

\begin{tabular}{|c|c|c|c|}
\hline Construct & Number of items & Factor loadings & $\begin{array}{c}\text { Cronbach's alpha } \\
\text { of construct }\end{array}$ \\
\hline \multirow[t]{3}{*}{ Family political discussion } & How often do you discuss politics with your father? & 0.646 & 0.730 \\
\hline & How often do you discuss politics with your mother? & 0.683 & \\
\hline & How often do you discuss politics with your family members other than parents? & 0.627 & \\
\hline \multirow[t]{2}{*}{ Peer political discussion } & How often do you discuss politics with your friends and classmates with different views? & 0.908 & 0.898 \\
\hline & How often do you discuss politics with your friends and classmates with similar views? & 0.908 & \\
\hline Political party discussion & How often do you discuss politics with members of political organisations on campus? & 0.902 & 0.891 \\
\hline \multirow{7}{*}{$\begin{array}{l}\text { Attempts to influence } \\
\text { the political process }\end{array}$} & How often do you participate in attempting to influence the political views of others? & 0.525 & 0.918 \\
\hline & How often do you participate in writing letters to the newspapers about political matters? & 0.398 & \\
\hline & How often do you participate in presenting your views to politicians (e.g. by signing petitions)? & 0.621 & \\
\hline & How often do you participate in the activities of a political party? & 0.774 & \\
\hline & How often do you participate in political protest marches/political sit-ins/demonstrations? & 0.743 & \\
\hline & How often do you participate in attending political rallies? & 0.744 & \\
\hline & How often do you participate in the activities of the youth movement of a political party? & 0.767 & \\
\hline
\end{tabular}


students is: 'Are you/did you participate in the following activities recently?' (community youth club activities, community environmental activities, community sanitation programmes, neighbourhood safety activities and sports and games). The response categories are 1, 'Yes'; 2, 'No'. These are aggregated to form the civic skills index.

\section{Statistical approach}

Data analysis is conducted at three levels, namely univariate, bivariate and multivariate using simple frequency distributions, proportions, cross-tabulations and multiple regression. Table 1 shows the results of the factor analysis, using Varimax rotation. This was conducted to examine the factor structure of the main dependent, political engagement of the youth. This part of the analysis yielded four dimensions of the dependent variables (family political discussion, peer political discussion, political party discussion and actual attempts to influence the political process). The general strategy is to examine the relationship between the sociodemographic variables and control variables on the one hand and each of the dependent variables on the other hand. Finally, for the multivariate analysis, we use the logit regression model by dichotomising each of the four dimensions of political engagement variables. Each of the four dependent variables is dichotomised into 'low' and 'high' engagement by splitting the summated scores at their means. In the logit regression model, the independent variables are the set of covariates $X=X_{1}, X_{2}, . ., X_{k}$ in the model, given as:

$\operatorname{logit}(p)=\log \left[\frac{\pi}{1-\pi}\right]=\alpha+\beta_{1} X_{1}+\beta_{2} X_{2}+\ldots+\beta_{k} X_{k}$

[Eqn 1]

Where $\frac{\pi}{1-\pi}$, the odds ratio, is the ratio of probability of 1 to probability of 0 . Mathematically, the odds ratio is bounded between 0 and $+\infty$, and the log odds assume any number between $-\infty$ and $+\infty$. Taking the exponent of both sides of the equation, it is very straightforward to conduct the maximum likelihood estimation in order to obtain the parameter estimates of the intercept $\alpha$ and slopes $\beta_{1}, \beta_{2}, . ., \beta_{k}$ in the model. The reference categories of each levels of the independent and control variables have an odds ratio value of ' 1 '.

\section{Results}

Table 2 shows the distribution of the sample characteristics. There are more female participants $(60 \%)$ than male participants (40\%). Twenty-seven per cent of the respondents aged between 17 and 19 years, while $73 \%$ of the respondents aged between 20 and 26 years. Sixty-nine per cent of the respondents are black African, 26 per cent are white people, while mixed race, Indian or Asians and other groups constitute $5 \%$ of the total sample. Fifty-one per cent and $50 \%$ of the respondents' fathers and mothers have tertiary educational qualifications, while $40 \%$ of the fathers and mothers have some secondary and secondary education, respectively; only $9 \%$ and $10 \%$, respectively, of the parents have no education or primary education.
Sixty per cent of the respondents live with both parents at home, while $29 \%$ live with a single parent. Sixty-eight per cent of the respondents perceive their families as having the same socio-economic level as other families in their neighbourhoods compared with $19 \%$ and $13 \%$, respectively, who perceive their families as being poorer and richer than most families in their neighbourhood. Sixty-eight per cent of the respondents are Christian (Protestant), 20\% are Christian (Catholic), while other religious groups constitute $11 \%$ of the total sample. For the purposes of this study, it is significant to note that the mean age of the respondents is 21.11 years. Thus, the bulk of the youth in the study were born before or around the time of the democratic transition in 1994, a cohort of South Africans that has been dubbed the 'born frees'.

Table 3 presents the results of the bivariate analysis of the relationship between selected background characteristics of the respondents and religions variables on the one hand and the four political engagement variables on the other hand. The only religion variable that is significantly associated with all the political engagement variables at the bivariate level is

TABLE 2: Sample characteristics.

\begin{tabular}{|c|c|c|}
\hline Variable & Number & Percentage \\
\hline \multicolumn{3}{|l|}{ Gender } \\
\hline Male & 448 & 39.6 \\
\hline Female & 682 & 60.4 \\
\hline \multicolumn{3}{|l|}{ Age } \\
\hline $17-19$ years & 275 & 27.4 \\
\hline $20-26$ years & 727 & 72.6 \\
\hline \multicolumn{3}{|l|}{ Race } \\
\hline Black people & 779 & 69.2 \\
\hline White people & 291 & 25.8 \\
\hline Mixed race people (Indian, Asian or Others) & 56 & 5.0 \\
\hline \multicolumn{3}{|l|}{ Home language } \\
\hline English & 129 & 11.5 \\
\hline Afrikaans & 302 & 26.9 \\
\hline IsiZulu, IsiXhosa, IsiNdebele, SiSwati & 147 & 13.1 \\
\hline North Sotho, Sesotho, Setswana, Sepedi & 494 & 44.0 \\
\hline Tshivenda, Xitsonga, Other African languages & 51 & 4.5 \\
\hline \multicolumn{3}{|l|}{ Father's education } \\
\hline None or primary education & 93 & 9.3 \\
\hline Some secondary or matric Grade 12 & 397 & 39.9 \\
\hline College diploma, undergraduate degree or postgraduate degree & 505 & 50.8 \\
\hline \multicolumn{3}{|l|}{ Mother's education } \\
\hline None or primary education & 105 & 9.5 \\
\hline Some secondary or matric grade 12 & 445 & 40.1 \\
\hline College diploma, undergraduate degree or postgraduate degree & 559 & 50.4 \\
\hline \multicolumn{3}{|l|}{ At home, live with which parents or guardian } \\
\hline Living with two parents & 676 & 59.8 \\
\hline Living with a single parent at a time & 324 & 28.6 \\
\hline Living with other relatives (aunt, uncle, grandparent) & 88 & 7.8 \\
\hline Living with guardian or foster parent or living alone & 43 & 3.8 \\
\hline \multicolumn{3}{|l|}{ Family socio-economic status } \\
\hline A lot or a little poorer than most & 215 & 19.0 \\
\hline About the same amount of money as most & 768 & 67.8 \\
\hline A lot or a little richer than most & 149 & 13.2 \\
\hline \multicolumn{3}{|l|}{ Respondent's religious affiliation } \\
\hline Christian (Protestant) & 678 & 68.0 \\
\hline Christian (Catholic) & 203 & 20.4 \\
\hline Other religion & 116 & 11.6 \\
\hline
\end{tabular}


TABLE 3: Relationship between covariates and political engagement

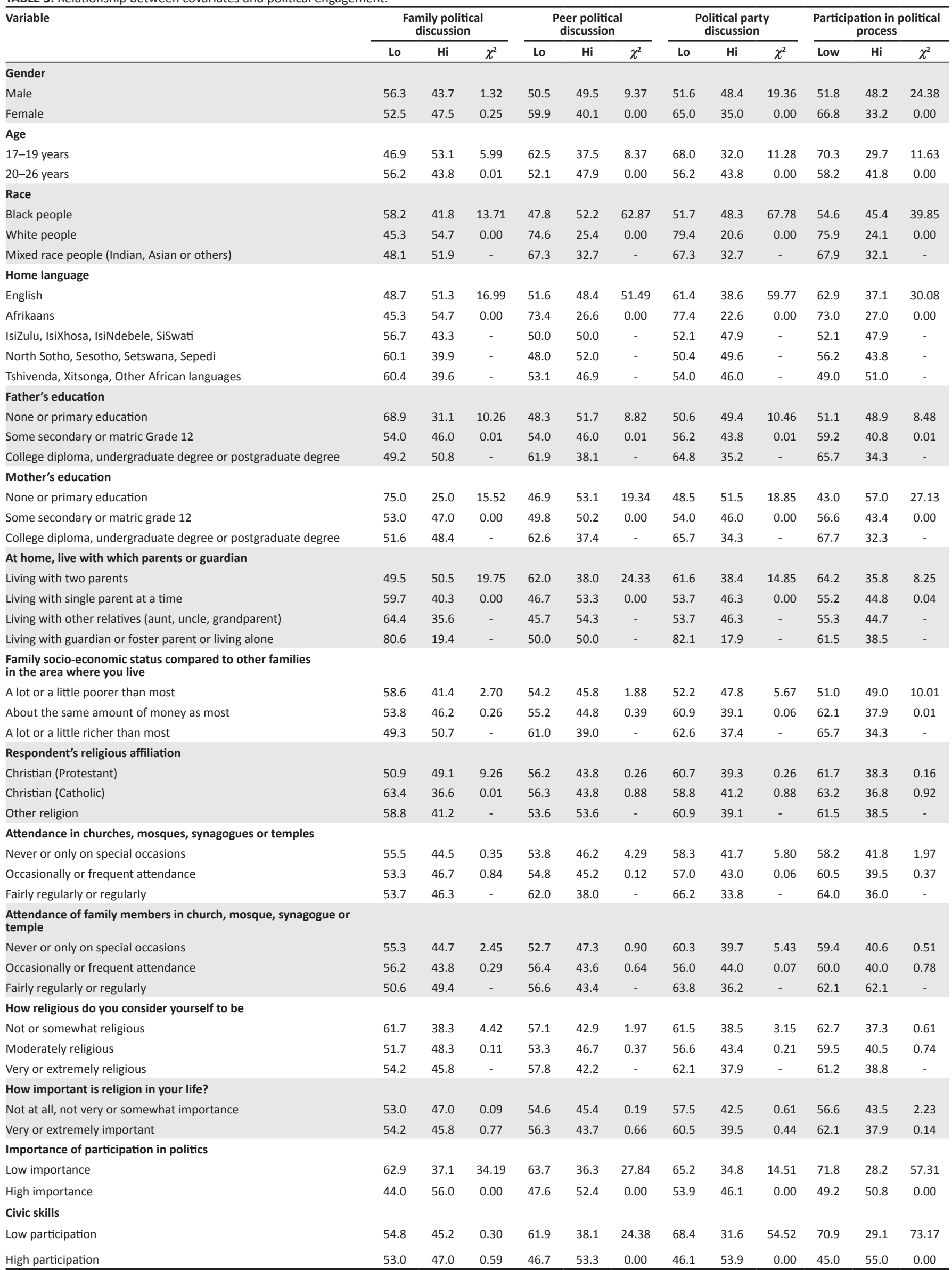


the student's perception of the importance of religion in the youth's life; when the youth perceive that politics is important, they are more likely to engage politically. Gender is significantly associated with all the political engagement variables except family political discussion; males have high rates of engagement compared to females. Also, age is significantly associated with all the political engagement variables with the exception of family political discussion; youth aged 20-26 years have higher levels of engagement than youth aged 17-19 years.

Apart from family political discussion where white people have higher level of political engagement, black Africans have higher levels of political engagement than white people and other race groups, especially in the domain of peer political discussion. Moreover, apart from the domain of family political discussion where Afrikaans-speaking youth have higher level of political engagement, Mnguni-speaking youth have higher levels of political engagement in every other domain of political engagement than any other language group. As far as education is concerned, higher parental education appears to engender only family political discussion because in every other domain of political engagement lower parental education is associated with higher level of political engagement. Youth who live with both parents at home have higher levels of political engagement only in the domain of family political discussion, whereas those who live with single parents at home have higher levels of political engagement in all other domains of political engagement.

The SES of a youth's family is significantly associated with the engagement of the youth in the political process, while it is marginally associated with political party discussion. Finally, apart from family political discussion, the civic skills index is significantly and positively associated with political engagement.

Table 4 shows the results of the logit model of religious effects on political engagement. After controlling for all the variables in the model, the only religion variables that are significant predictors of political engagement of the youth are religiosity and the importance of religion in the young person's life. Self-rated religiosity and perception of the youth on the importance of religion in their lives are the only two dimensions of religion that significantly predict the political engagement of the youth although their influences on young person's political engagement are in opposite directions. While religiosity is positively associated with peer political discussion and attempts to influence the political process, importance of religion in the young people's lives is inversely associated with the two aspects of political engagement.

Specifically, youth who perceive themselves as moderately religious and extremely religious are 2.14 and 3.17 times, respectively, more likely to engage in peer political discussion compared to youth who perceive themselves as not religious at all. Moreover, youth who perceive themselves as either moderately religious or extremely religious are 2.71 and 4.24 times, respectively more likely to engage in attempts to influence the political process compared to their counterparts who are not religious at all. On the other hand, the odds of youth who report that religion is very important or extremely important in their lives engaging in peer political discussion decrease by $61 \%$, while the odds of these youth engaging in attempts to influence the political process decrease by $4 \%$ compared to those who report that religion is not at all important in their lives.

As far as the control variables are concerned, gender, race, ethnicity as measured by home language, family structure, family's SES and civic skills are the only control variables that are significant predictors of political engagement of the youth. Males are more likely than females to engage in political party discussions and also to engage in attempts to influence the political process. Specifically, the odds of female respondents engaging in political party discussions and participating in the political process decreases by $60 \%$ and $65 \%$, respectively, compared to their male counterparts.

Race and ethnicity are significant predictors of political engagement of the youth. Both white and mixed race youths are less likely than black African youth to engage in peer political discussion and participation in the political process, while white youth are less likely to engage in attempts to influence the political process compared to black Africans. For example, the odds of whites and mixed race engaging in peer political discussions decreases by $28 \%$ and $30 \%$, respectively, while the odds of white respondents engaging in attempts to influence the political process decreases by $19 \%$ compared to black Africans. Young people who speak Tshivenda, Xitsonga and other African languages are less likely to engage in peer political discussions compared to those who speak English.

Family structure is a significant predictor of aspects of political engagement of the youth. Youth who live in a singleparent home are more likely to engage in peer political discussion compared to those who live in a two-parent home. The odds of youth who live in a single-parent home engaging in peer political discussion increases by $57 \%$ compared to those of youth who live with both parents at home. Youth who live with either a guardian or alone are less likely to engage in both family political and political party discussions but more likely to engage in peer political discussions. For example, the odds of youth who do not live with a family member engaging in family political discussion and political party discussion decreases by $21 \%$ and $24 \%$, respectively, compared to their counterparts who live with both parents. However, youth who live with guardians, foster parents or alone are 2.76 times more likely than those who live with both parents to engage in peer political discussion. Finally, young people who possess civic skills are more likely to participate in every dimension of political engagement with the exception of peer political discussion. 
TABLE 4: Logit model of religion effects on youth political engagement.

\begin{tabular}{|c|c|c|c|c|c|c|c|c|}
\hline \multirow[t]{2}{*}{ Variable } & \multicolumn{2}{|c|}{$\begin{array}{l}\text { Family political } \\
\text { discussion }\end{array}$} & \multicolumn{2}{|c|}{$\begin{array}{l}\text { Peer political } \\
\text { discussion }\end{array}$} & \multicolumn{2}{|c|}{$\begin{array}{l}\text { Political party } \\
\text { discussion }\end{array}$} & \multicolumn{2}{|c|}{$\begin{array}{l}\text { Participation in political } \\
\text { process }\end{array}$} \\
\hline & $B$ & $\operatorname{Exp}(B)$ & $B$ & $\operatorname{Exp}(B)$ & $B$ & $\operatorname{Exp}(B)$ & $B$ & $\operatorname{Exp}(B)$ \\
\hline Male (Ref.) & - & 1.000 & - & 1.000 & - & 1.000 & - & 1.000 \\
\hline Female & 0.106 & 1.112 & -0.080 & 0.923 & $-0.509 * * *$ & $0.601 * * *$ & $-0.423 * * *$ & 0.655 \\
\hline $17-19$ years (Ref.) & - & 1.000 & - & 1.000 & - & 1.000 & - & 1.000 \\
\hline $20-26$ years & -0.039 & 0.962 & 0.271 & 1.312 & 0.388 & 1.475 & 0.327 & 1.387 \\
\hline Black people (Ref.) & - & 1.000 & - & 1.000 & - & 1.000 & - & 1.000 \\
\hline White people & 0.275 & 1.317 & $-1.257 * * *$ & $0.284 * * *$ & -0.929 & 0.395 & $-1.649 * * *$ & $0.192 * * *$ \\
\hline Mixed race people (Indian, Asian or Others) & 0.183 & 1.201 & $-1.212 * * *$ & $0.298 * * *$ & -0.398 & 0.672 & -0.831 & 0.435 \\
\hline English (Ref.) & - & 1.000 & - & 1.000 & - & 1.000 & - & 1.000 \\
\hline Afrikaans & -0.180 & 0.835 & -0.101 & 0.904 & -0.192 & 0.826 & 0.381 & 1.464 \\
\hline IsiZulu, IsiXhosa, IsiNdebele, SiSwati & -0.490 & 0.613 & -0.510 & 0.600 & 0.037 & 1.037 & -0.418 & 0.658 \\
\hline North Sotho, Sesotho, Setswana, Sepedi & -0.291 & 0.748 & -0.277 & 0.758 & 0.183 & 1.200 & -0.143 & 0.867 \\
\hline Tshivenda, Xitsonga, Other African languages & -0.590 & 0.555 & $-1.412 * * *$ & $0.244 * * *$ & -0.584 & 0.557 & -0.004 & 0.996 \\
\hline \multicolumn{9}{|l|}{ Father's education } \\
\hline None or primary education (Ref.) & - & 1.000 & - & 1.000 & - & 1.000 & - & 1.000 \\
\hline Some secondary or matric Grade 12 & -0.269 & 0.764 & -0.092 & 0.912 & 0.333 & 1.395 & 0.363 & 1.438 \\
\hline College diploma, undergraduate degree or postgraduate degree & -0.201 & 0.818 & 0.317 & 1.373 & 0.565 & 1.759 & 0.684 & 1.981 \\
\hline \multicolumn{9}{|l|}{ Mother's education } \\
\hline None or primary education (Ref.) & - & 1.000 & - & 1.000 & - & 1.000 & - & 1.000 \\
\hline Some secondary or matric grade 12 & 0.817 & 2.264 & 0.300 & 1.350 & -0.045 & 0.956 & -0.473 & 0.623 \\
\hline College diploma, undergraduate degree or postgraduate degree & 0.920 & 2.509 & -0.080 & 0.923 & -0.306 & 0.737 & -0.641 & 0.527 \\
\hline Living with two parents (Ref.) & - & 1.000 & - & 1.000 & - & 1.000 & - & 1.000 \\
\hline Living with single parent at a time & -0.269 & 0.764 & $0.448 * * *$ & $1.565 * * *$ & -0.090 & 0.914 & 0.046 & 1.047 \\
\hline Living with other relatives (aunt, uncle, grandparent) & 0.099 & 1.104 & 0.519 & 1.680 & 0.105 & 1.111 & 0.278 & 1.321 \\
\hline Living with guardian or foster parent or living alone & $-1.587 * * *$ & $0.205 * * *$ & $1.014 * * *$ & $2.758 * * *$ & $-1.440 * * *$ & $0.237 * * *$ & -0.498 & 0.607 \\
\hline A lot or a little poorer than most (Ref.) & - & 1.000 & - & 1.000 & - & 1.000 & - & 1.000 \\
\hline About the same amount of money as most & 0.127 & 1.135 & 0.200 & 1.222 & -0.350 & 0.705 & $-0.612 * * *$ & $0.542 * * *$ \\
\hline A lot or a little richer than most & -0.040 & 0.961 & 0.001 & 1.001 & -0.279 & 0.756 & -0.669 & 0.512 \\
\hline Christian (Protestant) (Ref.) & - & 1.000 & - & 1.000 & - & 1.000 & - & 1.000 \\
\hline Christian (Catholic) & -0.288 & 0.749 & 0.034 & 1.035 & -0.028 & 0.972 & 0.088 & 1.092 \\
\hline Other religion & -0.486 & 0.615 & 0.198 & 1.219 & -0.079 & 0.924 & 0.139 & 1.149 \\
\hline \multicolumn{9}{|l|}{ Respondent attendance } \\
\hline Never or only on special occasions (Ref.) & - & 1.000 & - & 1.000 & - & 1.000 & - & 1.000 \\
\hline Occasionally or frequent attendance & -0.183 & 0.832 & -0.224 & 0.799 & 0.039 & 1.039 & -0.340 & 0.711 \\
\hline Fairly regularly or regularly & -0.398 & 0.671 & -0.417 & 0.659 & 0.005 & 1.005 & -0.299 & 0.741 \\
\hline \multicolumn{9}{|l|}{ Family attendance } \\
\hline Never or only on special occasions (Ref.) & - & 1.000 & - & 1.000 & - & 1.000 & - & 1.000 \\
\hline Occasionally or frequent attendance & 0.088 & 1.092 & -0.406 & 0.666 & -0.238 & 0.788 & -0.204 & 0.815 \\
\hline Fairly regularly or regularly & 0.468 & 1.597 & -0.319 & 0.727 & -0.380 & 0.684 & -0.207 & 0.813 \\
\hline Not or somewhat religious (Ref.) & - & 1.000 & - & 1.000 & - & 1.000 & - & 1.000 \\
\hline Moderately religious & 0.513 & 1.671 & $0.763 * * *$ & $2.144 * * *$ & 0.573 & 1.774 & $0.996 * * *$ & $2.707 * * *$ \\
\hline Very or extremely religious & 0.324 & 1.383 & $1.216 * * *$ & $3.373 * * *$ & 0.547 & 1.728 & $1.444 * * *$ & $4.238 * * *$ \\
\hline Religion not at all, not very or somewhat importance (Ref.) & - & 1.000 & - & 1.000 & - & 1.000 & - & 1.000 \\
\hline Religion very or extremely important & -0.479 & 0.619 & $-0.494 * * *$ & $0.610 * * *$ & -0.358 & 0.699 & $-0.746 * * *$ & $0.474 * * *$ \\
\hline Low importance of participation in politics (Ref.) & - & 1.000 & - & 1.000 & - & 1.000 & - & 1.000 \\
\hline High importance of participation in politics & $0.734 * * *$ & $2.083 * * *$ & 0.909 & 2.483 & $0.815 * * *$ & $2.260 * * *$ & $1.113 * * *$ & $3.042 * * *$ \\
\hline
\end{tabular}

***, significant at 0.001 level.

\section{Discussion and conclusion}

The simultaneous phenomenal growth of religious influences as manifested in the proliferation of religious organisations and the increasing role of religion in engendering positive youth development is what motivated this study. The underlying question we sought to answer in the study is: If religion is increasingly contributing to moving youth away from anti-social behaviours such as alcohol and drug use and abuse, is it diverting them towards pro-social behaviours such as political engagements? We sought to answer this question with a sample of undergraduate students across the three campuses of the North-West University in South Africa.
Four dimensions of religion were measured to see how they affect four dimensions of political engagement. We also examined the effects of gender, age, race, ethnicity, family structure, family SES, parental education and civic skills as control variables.

As far as religion's effect on political engagement of the youth is concerned, first, we found that merely being a member of a religious organisation did not predict youth involvement in political activities, a finding which is contrary to some existing studies in the Western context (e.g. Diaz 1996; Putnam 1993a, 1993b; Verba et al. 1995; Wald 1997). For example, Verba et al. (1995) found that Protestants were 
more involved politically than Catholics because of the denominational differences between the two religious organisations in providing members with the ability to participate in politics; in fact, they argued that Catholic churches often provide fewer opportunities for lay involvement.

However, the finding of this study is consistent with several other existing studies, that found no denominational differences with regard to members' participation in politics (e.g. Djupe \& Grant 2001; Jones-Correa \& Leal 2001). For example, Jones-Correa and Leal (2001) note as their reason for the finding for the null hypothesis that there is no difference between Christian denominations and that the central importance of churches may not be that they inculcate civic skills in their members, but that they serve as important conduits of political information and recruitment (see also, Ammerman 1997; Djupe \& Grant 2001).

The fact that frequency of religious attendance by the youth was not found to be a significant predictor of political engagement of the youth could be because of the differences in the emphasis different religious traditions put on politics. For example, Djupe and Grant (2001) found in their study in the United States that while African-American and Evangelical Protestants said they were active in church to better the nation, majority of them said they preferred religious activity over political activity. In a situation like this where political messages are not emphasised by a religious tradition, engagement in politics would hardly be dependent on the frequency of church attendance.

Out of the four dimensions of religion, only self-rated religiosity and importance of religion in the lives of the youth were found to be significant predictors of the political engagement of the youth, albeit their respective influences being in opposite directions. Religiosity was positively associated with youth peer political discussion and attempts to influence the political process, while importance of religion was negatively associated with these two domains of political engagement. These findings may appear contradictory but in fact they are not because the two are conceptually distinct. In fact, this finding is akin to the finding by Djupe and Grant's (2001) in regard to African-American Protestants and white Evangelical Protestants in the United States who prefer religious activity over political activity even though they are active in the church 'in order to better the Nation'. It is plausible that people who consider religion as important in their lives consider any non-religious activity, including politics, as less important.

The fact that males are more likely than females to engage in politics is consistent with the existing participation literature across several contexts (e.g. Coffe \& Bolzendahl 2011; Kenworthy \& Malami 1999; Nabanech 2012; Tadros 2011). This gender gap in political engagement or participation has been generally attributed to educational inequality, or the lack of education or skills or formal training for women (e.g. Bauer 2009; Nabanech 2012). Moreover, one cannot ignore the patriarchal nature of most societies, especially, in Africa, which views politics (i.e. political affairs and decision-making) as mostly a male domain (Grasso 2013; Sossou 2011).

The finding that black Africans are more politically active than their white and mixed race counterparts in this study is hardly surprising given the historical role of black Africans, especially, African youth, in the struggle to overthrow the apartheid state. It is significant to note that this generation of black African youth is the offspring of the 1970s and 1980s generations who cut their political teeth at predominantly black radical institutions such as Fort Hare, and Universities of the North and Western Cape.

We also found that living with a single parent at home was positively associated with youth's engagement in peer political discussion compared to living with those who live with either both parents or a guardian, foster parent or living alone. We are not aware of any empirical evidence for this finding but believe that this finding makes sense heuristically because in the absence of the husband-wife dyad of the family system, single parents may be too preoccupied with running the household to be available for discussion with their children; in such a situation, the peer system becomes an attractive alternative for socialisation purposes. Civic skills possessed by the youth were positively associated with family political discussion, political party discussion and attempts to influence the political process. While with the present cross-sectional data, we are not in a position to determine whether the civic skills were church-gained or derived from secular sources; Djupe and Grant (2001) found in their study that church-gained civic skills did not increase political participation of their subjects. On the other hand, Finlay and Flanagan (2009) have noted that in the United States, young people's interest in politics and community engagement increased simultaneously as they advanced in education.

In conclusion, the answer to the question as to whether religion impacts political participation by the youth is that it ultimately depends upon which aspect of religion one is looking at. Religion as a moral force does indeed affect pro-social behaviours such as political participation as a crucial element of a society's social structure as evidenced by the role of social structural elements such as age, ethnicity, education and family structure. However, as far as non-electoral political engagement by the youth is concerned, the acquisition of civic skills by the youth is the most important factor.

\section{Recommendations}

Based on the foregoing findings of this study, two recommendations, one methodological and the other substantive, are apparent. First, methodologically, while the study is based on a sample of youth at the tertiary level of the South African educational system and therefore may be 
selective of young persons who are already morally upright, future research in the area would do well by using a more diverse sample which can be generalised to the entire population of youth in the country. Second, on the substantive level, given the intensely political nature of South Africa, religious organisations should strive to enhance the political participation of the youth by helping them to acquire vital civic skills through their teachings and practices.

\section{Acknowledgements}

Special thanks to Dr Elizabeth Biney a post-doctoral Fellow, for helping to put this manuscript together.

\section{Competing interests}

The author declares that no competing interest exists.

\section{Authors' contributions}

I declare that I am the sole author of this research article.

\section{Ethical consideration}

This article followed all ethical standards for research without direct contact with human or animal subjects.

\section{Funding information}

This research received no specific grant from any agency in the public, commercial or not-for-profit sectors.

\section{Data availability statement}

Data are available to any interested person for purposes of replication or validation.

\section{Disclaimer}

The views and opinions expressed in this article are those of the author and do not necessarily reflect the official policy or position of any affiliated agency of the author.

\section{References}

Ammerman, N.T., 1997, Congregation and community, Rutgers University Press, New Brunswick, NJ.

Amoateng, A.Y., 2015, 'The end of politics by the youth? Higher education, youth identity and recession of political participation by South Africa's "Born-frees": The case of undergraduate students at a Public University', International Journal of the African Renaissance Studies 10(1), 102-119. https://doi.org/10.1080/18186874.2 015.1050218

Amoateng, A.Y., Barber, B.K. \& Erickson, L.D., 2006, 'Family predictors of adolescent substance use: The case of high school students in the Cape Metropolitan Area, Cape Town, South Africa', Journal of Child and Adolescent mental Health 18(1), 7-15. https://doi.org/10.1080/18186874.2015.1050218

Amoateng, A.Y., Setlalentoa, B.M.P. \& Udomboso, C.G., 2017, 'Does religion affect Alcohol use and Cigarette Smoking among Students at North-West University, South Africa?', African Population Studies 31(1), 3212-3224. https://doi. org/10.11564/31-1-954

Armingeon, K. \& Schädel, L., 2015, 'Social inequality in political participation: The dark sides of individualisation', West European Politics 38(1), 1-27. https://doi.org/10. 1080/01402382.2014.929341

Bauer, J., 2009, 'Women and the 2005 elections in Liberia', Journal of Modern African Studies 47(2), 193-211. https://doi.org/10.1017/S0022278X09003802
Bratton, M., 1999, 'Political participation in a new democracy: Institutional considerations from Zambia', Comparative Political Studies 32(5), 549-588. https://doi.org/10.1177/0010414099032005002

Chatora, A., 2012, Encouraging political participation in Africa: The potential of social media platforms, Institute for Security Studies, Pretoria, pp. 1-12.

Chauke, T.M., Van der Heever, H. \& Hoque, M.E., 2015, 'Alcohol use amongst learners in rural high school in South Africa', African Journal of Primary Health Care and Family Medicine 7(1), 1-6. https://doi.org/10.4102/phcfm.v7i1.755

Coffe, H. \& Bolzendahl, C., 2011, 'Gender gaps in political participation across subSaharan African Nations', Social Indicators Research 102, 245-264. https://doi. org/10.1007/s11205-010-9676-6

Crompton, M., 1998, Children, spirituality, religion and social work, Ashgate Publishing, Aldershot.

Cross, W. \& Young, L., 2008, 'Factors influencing the decision of the young politically engaged to join a political party: An Investigation of the Canadian Case', Party Politics 14(3), 345-369. https://doi.org/10.1177/1354068807088126

Diaz, W., 1996, 'Latino participation in America: Associational and political roles', Hispanic Journal of Behavioral Sciences 18(2), 154-174. https://doi.org/ 10.1177/07399863960182005

Djupe, P.A. \& Grant, J.T., 2001, 'Religious institutions and political participation in America', Journal for the Scientific Study of Religion 40(2), 303-314. https://doi. org/10.1111/0021-8294.00057

Donahue, M., 1995, 'Religion and the well-being of adolescents', Journal of Socia Issues 51(2), 145-160. https://doi.org/10.1111/j.1540-4560.1995.tb01328.x

Esser, F. \& De Vreese, C.H., 2007, 'Comparing young voters' political engagement in the United States and Europe', American Behavioral Scientist 50(9), 1195-1213. https://doi.org/10.1177/0002764207299364

Evans, T.D., Cullen, F., Dunaway, R.G. \& Burton, Jr., V., 1995, 'Religion and crime re-examined: The impact of religion, secular controls, and social ecology on adult criminality', Criminology 33(2), 195-217. https://doi.org/10.1111/j.17459125.1995.tb01176.x

Finlay, A. \& Flanagan, C., 2009, Making educational progress: Links to civic engagement during the transition to adulthood, Working Paper No. 67, Tufts University, CIRCLE, Medford, MA, viewed 03 March 2015, from http://www.civicyouth.org/PopUps/ WorkingPapers/WP_67_Finley_Flanagan.pdf/.

Flanagan, C. \& Levine, P., 2010, 'Civic engagement and the transition to adulthood', Future of Children 20(1), 159-179. https://doi.org/10.1353/foc.0.0043

Flisher, A.J., Ziervogel, C.F., Chalton, D.O., Leger, P.H. \& Robertson, B.A., 1996, 'Risktaking behaviour of Cape Peninsula high-school students. Part IX. Evidence for a syndrome of adolescent risk behaviour', South African Medical Journal 86(9), 1090-1093.

Garcia-Penalosa, C. \& Konte, M., 2013, Why are women less democratic than men? Evidence from sub-Saharan African countries, CESifo Working Papers Series No. 4524, pp. 1-43, CESifo Group, Munich.

Gore, A., 2003, 'Foreword', in R.M. Lerner \& P.L. Benson (eds.), Developmental assets and asset-building communities: Implications for research, policy, and practice, Kluwer Academic Publishers, Norwell, MA.

Grasso, M., 2013, 'The differential impact of education on young people's political activism: Comparing Italy and the United Kingdom', Comparative Sociology 12(1), 1-30. https://doi.org/10.1163/15691330-12341252

Henn, M. \& Foard, N., 2014, 'Social differentiation in young people's political participation: The impact of social and educational factors on youth political engagement in Britain', Journal of Youth Studies 17(3), 360-380. https://doi.org/1 $0.1080 / 13676261.2013 .830704$

Henn, M., Weinstein, M. \& Forrest, S., 2005, 'Uninterested youth? Young people's attitudes towards party politics in Britain', Political Studies 53(3), 556-578. https://doi.org/10.1111/j.1467-9248.2005.00544.x

Huckfeldt, R. \& Sprague, J., 1995, Citizens, politics, and social communication: Information and influence in an election campaign, Cambridge University Press, New York.

Inglehart, R. \& Norris, P., 2000, 'The developmental theory of the gender gap: Women's and men's voting behavior in global perspective', International Political Science Review 21(4), 441-463. https://doi.org/10.1177/0192512100214007

Isaksson, A.S., 2014, 'Political participation in Africa: The role of individual resources', Electoral Studies 34, 244-260. https://doi.org/10.1016/j.electstud.2013.09.008

Isaksson, A.-S., Kotsadam, A. \& Nerman, M., 2012, The gender gap in African political participation: Individual and contextual determinants, Working Papers in Economics no. 530, pp. 1-33, University of Gothenburg, Department of Economics, Gothenburg.

Jones-Correa, M.A. \& Leal, D.L., 2001, 'Political participation: Does religion matter?' Political Research Quarterly 54(4), 751-770. https://doi.org/10.1177/106591 290105400404

Kam, C.D. \& Palmer, C.L., 2008, 'Reconsidering the effect of education on political participation', Journal of Politics 70(3), 612-631. https://doi.org/10.1017/ S0022381608080651

Kenworthy, L. \& Malami, M., 1999, 'Gender inequality in political representation: A worldwide comparative analysis', Social Forces 78(1), 235-269. https://doi. org/10.2307/3005796

Kuenzi, M. \& Lambright, G., 2010, 'Who votes in Africa? An examination of electoral turnout in 10 African countries', Party Politics 17(6), 767-799. https://doi. org/10.1177/1354068810376779

Lerner, R.M., 2002, Concepts and theories of human development, 3rd edn., Erlbaum, Mahwah, NJ. 
Lerner, R.M., Brentano, C., Dowling, E.M. \& Anderson, P.M., 2002, 'Positive youth development: Thriving as a basis of personhood and civil society', New development: Thriving as a basis of personhood and civil society', New
Directions for Youth Development 2002 Fall 95, 11-33. https://doi.org/10. Directions for
1002/yd.14

Morojele, N.K., Kachieng'a, M.A., Mokoko, E., Nkoko, M.A., Parry, C.D. \& Nkowane, A.M. et al., 2006, 'Alcohol use and sexual behaviour among risky drinkers and bar and shebeen patrons in Gauteng Province, South Africa', Social Science and Medicine 62(1), 217-227. https://doi.org/10.1016/j.socscimed.2005.05.031

Nabanech, S., 2012, The power of women's political participation in ECOWAS, viewed 10 May 2014, from http://www.afard.org/allfichiers/Communication SatangNabaneh.pdf/.

Parry, C.D.M., Bhana, A., Myers, B., Pluddemann, A., Flisher, A.J., Peden, M.M. et al., 2002, 'Alcohol use in South Africa: Findings from the South African community epidemiology networks on drug use', Journal of Studies on Alcohol 63(4), 430435. https://doi.org/10.15288/jsa.2002.63.430

Putnam, R., 1993a, Making democracy work: Civic traditions in modern Italy, Princeton University Press, Princeton, NJ.

Putnam, R., 1993b, 'The prosperous community: Social capital and public life', The American Prospect 13(Spring), 35-42.

Resnick, D. \& Casale, D., 2011, The political participation of Africa's youth: Turnout, partisanship, and protest, Working paper // World Institute for Development partisanship, and protest, Working paper // World Institute for
Economics Research, No. 2011, p. 56, Afrobarometer, Accra, Ghana.

Resnick, D. \& Casale, D., 2014, 'Young populations in young democracies: Generational voting behaviour in sub-Saharan Africa', Democratization 21(6), 1172-1194. https://doi.org/10.1080/13510347.2013.793673

Roberts, A., Struwing, J. \& Grossberg, A., 2012, 'A vote of confidence: Gender differences in attitudes to electoral participation and experience in South Africa', Journal of African Elections 11(2), 7-36. https://doi.org/10.20940/JAE/2012/v11i2a1

Seggie, J.A., 2012, 'South Africa's youth', The South African Medical Journal 102(7), 587. https://doi.org/10.7196/SAMJ.6003

Serow, R. \& Dreyden, J., 1990, 'Community service among college and university students: Individual and institutional relationships', Adolescence 25(99), 553-566.

Sloam, J., 2013, 'Voice and equality': Young people's politics in the European Union', West European Politics 36(4), 836-858. https://doi.org/10.1080/01402382.2012.749652
Smith, C., 2003, 'Theorizing religious effects among American adolescents', Journal for the Scientific Study of Religion 42(1), 17-30. https://doi.org/10.1111/1468-5906. to1-1-00158

Smith, C. \& Denton, M.L., 2005, The religious and spiritual lives of American teenagers, p. 346, Oxford University Press, New York.

Smith, E.S., 1999, 'The effects of investments in the social capital of youth on political and civic behavior in young adulthood: A longitudinal analysis', Political Psychology 20(3), 553-580. https://doi.org/10.1111/0162-895X.00156

Sossou, M.-A., 2011, 'We do not enjoy equal political rights: Ghanaian women's perceptions on political participation in Ghana', Sage Open 1(1), 1-9.

Tadros, M., 2011, Women engaging politically: Beyond magic bullets and motorways, Pathways Policy Paper, Pathways of Women's Empowerment RPC, Brighton.

Teney, C. \& Hanquinet, L., 2012, 'High political participation, high social capital? A relational analysis of youth social capital and political participation', Social Science Research 41(5), 1213-1226. https://doi.org/10.1016/j.ssresearch.2012.03.012

UNDP, 2013, Enhancing youth political participation through the electoral cycle, UNDP, New York.

Verba, S. \& Nie, N., 1972, Participation in America: Political democracy and social equality, Harper \& Row, New York.

Verba, S., Schlozman, K.L. \& Brady, H., 1995, Voice and equality: Civic volunteerism in American politics, Harvard University Press, Cambridge, MA.

Wald, K.D., 1997, Religion and politics in the United States, 3rd edn., CQ Press, Washington, DC.

Wallace, J.M. \& Williams, D.R., 1997, 'Religion and adolescent health-compromising behavior', in J. Schvlenberg, J.L. Maggs \& K. Hurrelmann (eds.), Health risks and developmental transitions during adolescence, pp. 444-468, Cambridge University Press, New York

Wright, L., Frost, C. \& Wisecarver, S., 1993, 'Church attendance, meaningfulness of religion, and depressive symptomatology among adolescents', Journal of Youth and Adolescence 22, 559-568. https://doi.org/10.1007/BF01537716

Youniss, J.J., McLellan, J. \& Yates, M., 1999, 'Religion, community service, and identity in American youth', Journal of Adolescence 22(2), 243-253. https://doi.org/ 10.1006/jado.1999.0214 